Review

\title{
Characteristics and Applications of Canine In Vitro Models of Bladder Cancer in Veterinary Medicine: An Up-to-Date Mini Review
}

\author{
Łukasz Nowak $^{1, * \mathbb{D}}$, Wojciech Krajewski ${ }^{1}$, Bartosz Małkiewicz ${ }^{1}{ }^{(\mathbb{D}}$, Tomasz Szydełko ${ }^{1}$ and \\ Aleksandra Pawlak 2,*(i)
}

1 University Center of Excellence in Urology, Department of Minimally Invasive and Robotic Urology, Wroclaw Medical University, 50-556 Wroclaw, Poland; wk@softstar.pl (W.K.); bartosz.malkiewicz@umed.wroc.pl (B.M.); tomasz.szydelko1@gmail.com (T.S.)

2 Department of Pharmacology and Toxicology, Faculty of Veterinary Medicine, Wroclaw University of Environmental and Life Sciences, 50-375 Wroclaw, Poland

* Correspondence: 1llukasz.nowak@gmail.com (Ł.N.); aleksandra.pawlak@upwr.edu.pl (A.P.)

Citation: Nowak, Ł.; Krajewski, W.; Małkiewicz, B.; Szydełko, T.; Pawlak, A. Characteristics and Applications of Canine In Vitro Models of Bladder Cancer in Veterinary Medicine: An Up-to-Date Mini Review. Animals 2022, 12, 516. https://doi.org/10.3390/ani12040516 Academic Editor: Cinzia Benazzi

Received: 7 January 2022

Accepted: 17 February 2022

Published: 19 February 2022

Publisher's Note: MDPI stays neutral with regard to jurisdictional claims in published maps and institutional affiliations.

Copyright: (C) 2022 by the authors. Licensee MDPI, Basel, Switzerland. This article is an open access article distributed under the terms and conditions of the Creative Commons Attribution (CC BY) license (https:// creativecommons.org/licenses/by/ $4.0 /)$.
Simple Summary: Bladder cancer (BC) in dogs is often lethal at the time of diagnosis. Therefore, there is a constant need for novel research on improvements of its characterization and treatment. Due to high cost and limited number of available dog patients, in vitro models of canine BC have been increasingly used for the last 25 years. In the present article, we present existing in vitro models of canine BC, including available simple (two-dimensional) and more complex (three-dimensional) models.

\begin{abstract}
Bladder cancer (BC) constitutes approximately $2 \%$ of all spontaneously occurring cancers in dogs. It is characterized by a devastating clinical course in most cases, which emphasizes a constant need for the development of novel methods of disease characterization and treatment. Over the past years, advances in cell engineering have resulted in the development of various canine in vitro models of BC, emerging as complements for in vivo research. In this article, we aimed to review the available data on existing in vitro models of canine $\mathrm{BC}$, focusing primarily on their characteristics, applications in veterinary medicine, as well as advantages and disadvantages. The most commonly used in vitro models of canine BC comprise immortalized cell lines grown as adherent monolayers. They provide an unlimited supply of research material, however, they do not faithfully reflect the conditions prevailing in vivo, since the spatial cellular interactions are lost. The importance of the three-dimensional (3D) features of solid tumors in relation to carcinogenesis or drug response process has resulted in the development of the first canine 3D models of BC available for in vitro research. So far, results obtained with in vitro and in vivo research should be interpreted together. With the constantly growing complexity of in vitro models of BC cancer, animal-based research might be reduced in the future.
\end{abstract}

Keywords: canine; bladder; urothelial cancer; in vitro model

\section{Introduction}

Bladder cancer (BC) constitutes approximately $2 \%$ of all spontaneously occurring cancers in dogs [1]. With estimates that 4-6 million pet dogs develop cancer in the United States annually, this equates to more than 60,000 cases of BC in dogs each year [2]. More than $95 \%$ of canine BCs are urothelial carcinomas (UCs), also known as transitional cell carcinomas (TCCs). Most canine BCs are characterized by adverse histopathological features at the time of diagnosis, such as muscle infiltration and high cellular grade [1-3]. Distant metastases are initially found in about $20 \%$ of newly diagnosed cases, leaving most dogs incurable [1-3]. The devastating clinical course and poor survival outcomes in considerable number of dogs with BC emphasize a constant need for development of 
novel research tools used for disease characterization and treatment, primarily resulting in survival outcomes improvements.

Though obvious benefits that could be gained from the research of canine BC in vivo, there are some inevitable limitations (e.g., high cost, long duration, and insufficient numbers of pet dogs to test even a fraction of the new drugs, especially when considering various possible drug combinations), making extensive in vivo research difficult [1,2]. Current strategies to overcome these challenges include increased utilization of in vitro models. Their resemblance to the primary tumors in the context of molecular behavior and genomic landscape has been increasingly evaluated in the past few years. Moreover, advances in cell engineering have resulted in the development of novel complex in vitro models of canine $\mathrm{BC}$, emerging as unique complements for in vivo research.

In the present article, we aimed to review the available data on existing in vitro models of canine BC as a tool in veterinary research, focusing primarily on their characteristics, potential applications in veterinary medicine, and advantages and disadvantages. To the best of our knowledge, this is the first review summarizing the current evidence regarding this topic.

\section{Evidence Acquisition}

We conducted a literature search using two electronic databases, namely, Pubmed and Scopus. The most recent search was performed on 28 January 2022. Screening of the literature was conducted using the following search string: ("bladder" OR "transitional" OR "urothelial") AND ("cancer" OR "carcinoma" OR "neoplasm") AND ("in vitro" OR "model" OR "cell*" OR "culture") AND ("dog" OR "canine"). Auto-alerts in Medline were run, as well as reference lists of original articles and review articles for further eligible data. We exclusively included data regarding in vitro models of canine bladder TCC. Only papers in English were considered eligible without restrictions on publication year. The flow diagram of the study selection process is presented in Figure 1.

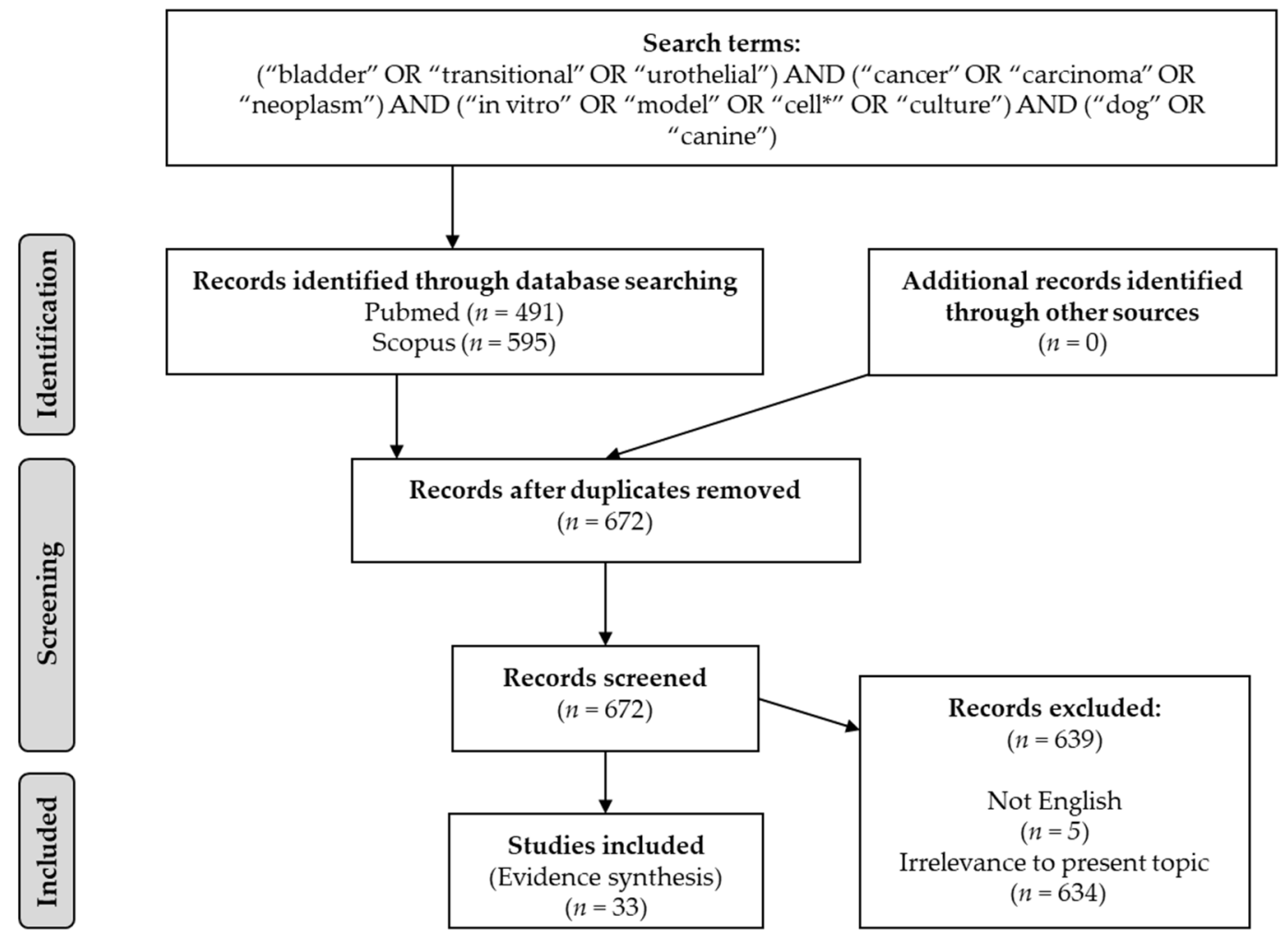

Figure 1. Flow diagram of study selection process. 


\section{Evidence Synthesis}

\subsection{Two Dimensional (2D) Models}

The most commonly used two dimensional (2D) models of canine BC comprise immortalized cell lines and primary cell cultures grown as adherent monolayers in appropriate media. The first immortalized canine BC cell line, called K9TCC, was established by Knapp et al. in 1995 [4]. Since then, several novel canine BC cell lines have been developed and described in the literature [5-10]. Almost all of these cell lines were established from invasive and metastatic tumors, benefiting the investigation of late tumor progression and metastatic lesions. Their baseline characteristics were presented in Table 1.

Table 1. Baseline characteristics of the available canine bladder cancer cell lines.

\begin{tabular}{|c|c|c|c|c|c|c|c|c|}
\hline \multirow{2}{*}{$\begin{array}{l}\text { Cell Line } \\
\text { Name }\end{array}$} & \multirow{2}{*}{$\begin{array}{l}\text { First } \\
\text { Report } \\
\text { Date }\end{array}$} & \multirow[b]{2}{*}{ Development } & \multicolumn{4}{|c|}{ Characteristics of Primary Tumor } & \multirow{2}{*}{$\begin{array}{l}\text { Doubling } \\
\text { Time }\end{array}$} & \multirow{2}{*}{$\begin{array}{c}\text { Reference } \\
\text { (First } \\
\text { Report) }\end{array}$} \\
\hline & & & $\begin{array}{c}\text { Breed of } \\
\text { Origin }\end{array}$ & $\begin{array}{c}\text { Age at } \\
\text { Sampling }\end{array}$ & Gender & $\begin{array}{l}\text { Pathological } \\
\text { Data }\end{array}$ & & \\
\hline K9TCC & 1995 & $\begin{array}{l}\text { Cultured cells from } \\
\text { bladder tumor } \\
\text { biopsy samples }\end{array}$ & Mixed breed & NR & Female & $\begin{array}{l}\text { Invasive } \\
\text { TCC }\end{array}$ & $24 \mathrm{~h}$ & {$[4]$} \\
\hline $\begin{array}{l}\text { K9TCC-PU- } \\
\text { AxA }\end{array}$ & 2009 & $\begin{array}{l}\text { Cultured cells from } \\
\text { bladder tumor } \\
\text { biopsy samples }\end{array}$ & NR & NR & Female & $\begin{array}{l}\text { Invasive } \\
\text { TCC G3 }\end{array}$ & $23.5 \mathrm{~h}$ & {$[5]$} \\
\hline $\begin{array}{l}\text { K9TCC-PU- } \\
\text { AxC }\end{array}$ & 2009 & $\begin{array}{l}\text { Cultured cells from } \\
\text { bladder tumor } \\
\text { biopsy samples }\end{array}$ & NR & NR & Female & $\begin{array}{l}\text { Invasive } \\
\text { TCC G3 }\end{array}$ & $36.2 \mathrm{~h}$ & [5] \\
\hline K9TCC-PU-In & 2009 & $\begin{array}{l}\text { Cultured cells from } \\
\text { bladder tumor } \\
\text { biopsy samples }\end{array}$ & $\begin{array}{l}\text { German } \\
\text { Shepherd }\end{array}$ & NR & Female & $\begin{array}{l}\text { Invasive } \\
\text { TCC G3 }\end{array}$ & $41.2 \mathrm{~h}$ & {$[5]$} \\
\hline $\begin{array}{l}\text { K9TCC-PU- } \\
\text { Mx }\end{array}$ & 2009 & $\begin{array}{l}\text { Cultured cells from } \\
\text { bladder tumor } \\
\text { biopsy samples }\end{array}$ & $\begin{array}{l}\text { German } \\
\text { Shepherd }\end{array}$ & NR & Female & $\begin{array}{l}\text { Invasive } \\
\text { TCC G3 }\end{array}$ & $23.5 \mathrm{~h}$ & [5] \\
\hline K9TCC-PU-Nk & 2009 & $\begin{array}{l}\text { Cultured cells from } \\
\text { bladder tumor } \\
\text { biopsy samples }\end{array}$ & NR & NR & Female & $\begin{array}{l}\text { Invasive } \\
\text { TCC G3 }\end{array}$ & $58.4 \mathrm{~h}$ & {$[5]$} \\
\hline K9TCC-PU-Pu & 2009 & $\begin{array}{l}\text { Cultured cells from } \\
\text { bladder tumor } \\
\text { biopsy samples }\end{array}$ & NR & NR & Female & $\begin{array}{l}\text { Invasive } \\
\text { TCC G3 }\end{array}$ & $51.8 \mathrm{~h}$ & {$[5]$} \\
\hline K9TCC-PU-Sh & 2009 & $\begin{array}{l}\text { Cultured cells from } \\
\text { bladder tumor } \\
\text { biopsy samples }\end{array}$ & Collie & NR & Female & $\begin{array}{l}\text { Invasive } \\
\text { TCC G3 }\end{array}$ & $29.1 \mathrm{~h}$ & [5] \\
\hline Bliley & 2012 & NR & $\begin{array}{l}\text { Shetland } \\
\text { Sheepdog }\end{array}$ & NR & Female & TCC & $20 \mathrm{~h}$ & [6] \\
\hline K9TCC\#1Lille & 2014 & $\begin{array}{l}\text { Cultured cells from } \\
\text { bladder tumor } \\
\text { biopsy samples }\end{array}$ & Pointer & 16 years & Female & $\begin{array}{l}\text { Invasive } \\
\text { TCC }\end{array}$ & $47.4 \mathrm{~h}$ & [7] \\
\hline K9TCC\#2Dakota & 2014 & $\begin{array}{l}\text { Cultured cells from } \\
\text { bladder tumor } \\
\text { biopsy samples }\end{array}$ & Bichon Fries & 13 years & Female & $\begin{array}{l}\text { Invasive } \\
\text { TCC }\end{array}$ & $31.96 \mathrm{~h}$ & [7] \\
\hline K9TCC\#4Molly & 2014 & $\begin{array}{l}\text { Cultured cells from } \\
\text { bladder tumor } \\
\text { biopsy samples }\end{array}$ & Maltese & 10 years & Female & $\begin{array}{l}\text { Invasive } \\
\text { TCC }\end{array}$ & $44.69 \mathrm{~h}$ & [7] \\
\hline K9TCC\#5Lilly & 2014 & $\begin{array}{l}\text { Cultured cells from } \\
\text { bladder tumor } \\
\text { biopsy samples }\end{array}$ & Mixed breed & 13 years & Female & $\begin{array}{l}\text { Invasive } \\
\text { TCC }\end{array}$ & $48.3 \mathrm{~h}$ & [7] \\
\hline LCTCC & 2015 & $\begin{array}{l}\text { Cultured cells from } \\
\text { bladder tumor } \\
\text { biopsy samples }\end{array}$ & NR & NR & NR & TCC & NR & [8] \\
\hline МСТСС & 2015 & $\begin{array}{l}\text { Cultured cells from } \\
\text { bladder tumor } \\
\text { biopsy samples }\end{array}$ & NR & NR & NR & TCC & NR & [8] \\
\hline MegTCC & 2015 & $\begin{array}{l}\text { Cultured cells from } \\
\text { bladder tumor } \\
\text { biopsy samples }\end{array}$ & NR & NR & NR & TCC & NR & [8] \\
\hline
\end{tabular}


Table 1. Cont.

\begin{tabular}{|c|c|c|c|c|c|c|c|c|}
\hline \multirow{2}{*}{$\begin{array}{l}\text { Cell Line } \\
\text { Name }\end{array}$} & \multirow{2}{*}{$\begin{array}{l}\text { First } \\
\text { Report } \\
\text { Date }\end{array}$} & \multirow[b]{2}{*}{ Development } & \multicolumn{4}{|c|}{ Characteristics of Primary Tumor } & \multirow{2}{*}{$\begin{array}{l}\text { Doubling } \\
\text { Time }\end{array}$} & \multirow{2}{*}{$\begin{array}{l}\text { Reference } \\
\text { (First } \\
\text { Report) }\end{array}$} \\
\hline & & & $\begin{array}{c}\text { Breed of } \\
\text { Origin }\end{array}$ & $\begin{array}{c}\text { Age at } \\
\text { Sampling }\end{array}$ & Gender & $\begin{array}{c}\text { Pathological } \\
\text { Data }\end{array}$ & & \\
\hline MonoTCC & 2015 & $\begin{array}{l}\text { Cultured cells from } \\
\text { bladder tumor } \\
\text { biopsy samples }\end{array}$ & NR & NR & NR & TCC & NR & {$[8]$} \\
\hline K9TCC-PU-An & 2015 & $\begin{array}{l}\text { Cultured cells from } \\
\text { bladder tumor } \\
\text { biopsy samples }\end{array}$ & $\begin{array}{l}\text { Scottish } \\
\text { Terrier }\end{array}$ & NR & Female & $\begin{array}{l}\text { Invasive } \\
\text { TCC }\end{array}$ & NR & {$[9]$} \\
\hline TihoDUrtTCC1506 & 2020 & $\begin{array}{l}\text { Cultured cells from } \\
\text { bladder tumor } \\
\text { biopsy samples }\end{array}$ & $\begin{array}{l}\text { Labrador } \\
\text { Retriever }\end{array}$ & 10 years & Female & $\begin{array}{c}\text { Invasive } \\
\text { TCC }\end{array}$ & $19.9 \mathrm{~h}$ & {$[10]$} \\
\hline
\end{tabular}

Abbreviations: $\mathrm{G}=$ grade; $\mathrm{NR}=$ not reported; $\mathrm{TCC}=$ transitional cell carcinoma.

The majority of canine BC cell lines express specific cancer-related markers, resembling those presented by the primary tumors in vivo. Due to differences in the development process (mainly related to primary tumor characteristics), the available canine TCC cell lines differ in terms of expressed biomarkers (Table 2). This allows for the selection of appropriate cell lines adapted to the research purposes, such as investigation of specific proteins and their potential impact on carcinogenesis or treatment response. Characterization of 8 canine BC cell lines (K9TCC, K9TCC-PU-AxA, K9TCC-PU-AxC, K9TCC-PU-Sh, K9TCC-PU-Mx, K9TCC-PU, K9TCC-PU-Nk, and K9TCC-PU-Pu) was provided by Dhawan et al. [5]. All cell lines revealed high expression of E-cadherin and cytokeratin. High cox-2 protein expression was present in all cell lines. The K9TCCAxA, K9TCC-PU-AxC, and K9TCC-PUIn cell lines were also characterized by high expression of p53 protein, whereas K9TCC, K9TCC-PU-Mx, K9TCC-PU-Nk, K9TCC-PU-Sh, and K9TCC-PU-Pu had low expression of p53 protein. Another available canine BC cell lines (K9TCC\#1Lillie, K9TCC\#2Dakota, K9TCC\#4Molly, K9TCC\#5Lilly) were characterized by Rathore et al. [7]. All cell lines highly or moderately expressed the cytokeratin. Cell proliferation marker Ki-67 was highly expressed in three of these cell lines, except K9TCC\#4 Molly. Expression of kinase-tyrosine receptors (EGFR, PDGDR) differed between cell lines. PDGFR was more expressed in K9TCC\#1Lillie, K9TCC\#2Dakota, and K9TCC\#4Molly than in the K9TCC\#5Lilly. EGFR was moderately expressed in all tested K9TCC, whereas VEGFR seemed to be not expressed. Moreover, Cox-2 was highly expressed in all cell lines [7].

To date, only a few studies have provided data regarding high-throughput molecular characterization of existing canine BC cell lines. Initial molecular characterization (including genotypic data) of several canine BC cell lines was performed by the Flint Animal Cancer Center (FACC) [11]. Subsequently, Das et al. conducted whole exome sequence analyses on 33 canine cancer cell lines, including canine BC cell lines [12]. Authors provided a wide database of somatic mutations that can be explored for their role in the development and progression of canine BC [12]. Further investigations of the cellular biology through molecular characterizations of canine BC cell lines may provide valuable information regarding cancer biology and play a crucial role in predicting the variable treatment responses. Thus, in vitro analysis of drug sensitivity in a background of known protein coding somatic mutations could be used to correlate drug sensitivity to the observed genomic profile in further research. 
Table 2. Histological and molecular characterization of available canine bladder cancer cell lines.

\begin{tabular}{|c|c|c|c|c|c|c|c|c|c|c|c|}
\hline \multirow[b]{2}{*}{$\begin{array}{l}\text { Cell Line } \\
\text { Name }\end{array}$} & \multicolumn{9}{|c|}{ Expression of Cancer-Related Markers } & \multirow{2}{*}{$\begin{array}{l}\text { Available } \\
\text { Molecular } \\
\text { Data }\end{array}$} & \multirow[b]{2}{*}{ Reference } \\
\hline & Uroplakin & Cytokeratin & $\begin{array}{c}\text { E- } \\
\text { Cadherin }\end{array}$ & Vimentin & Ki67 & PDGFR & EGFR & COX-2 & p53 & & \\
\hline K9TCC & NR & High & High & Moderate & NR & NR & NR & High & Low & $\begin{array}{l}\text { Array-based } \\
\text { CGH, CNV } \\
\text { analysis, } \\
\text { transcriptome } \\
\text { analysis }\end{array}$ & {$[4,5,9]$} \\
\hline $\begin{array}{c}\text { K9TCC-PU- } \\
\text { AxA }\end{array}$ & NR & High & High & Moderate & NR & NR & NR & High & High & NR & [5] \\
\hline $\begin{array}{c}\text { K9TCC-PU- } \\
\text { AxC }\end{array}$ & NR & High & High & High & NR & NR & NR & High & High & NR & [5] \\
\hline K9TCC-PU-In & NR & High & High & Moderate & NR & NR & NR & High & High & $\begin{array}{c}\text { Array-based } \\
\text { CGH, CNV } \\
\text { analysis }\end{array}$ & {$[5,9]$} \\
\hline $\begin{array}{c}\text { K9TCC-PU- } \\
\text { Mx }\end{array}$ & NR & High & High & Low & NR & NR & NR & High & Low & $\begin{array}{c}\text { Array-based } \\
\text { CGH, CNV } \\
\text { analysis }\end{array}$ & {$[5,9]$} \\
\hline $\begin{array}{c}\text { K9TCC-PU- } \\
\text { Nk }\end{array}$ & NR & High & High & Moderate & NR & NR & NR & High & Low & NR & [5] \\
\hline K9TCC-PU-Pu & NR & High & High & Moderate & NR & NR & NR & High & Low & $\begin{array}{c}\text { NR } \\
\text { Array-based }\end{array}$ & [5] \\
\hline K9TCC-PU-Sh & NR & High & High & Moderate & NR & NR & NR & High & Low & $\begin{array}{c}\text { CGH, CNV } \\
\text { analysis }\end{array}$ & {$[5,9]$} \\
\hline Bliley & NR & NR & NR & NR & NR & NR & NR & NR & NR & $\begin{array}{l}\text { Deep exome } \\
\text { analysis, } \\
\text { transcriptome } \\
\text { analysis }\end{array}$ & {$[6,11,12]$} \\
\hline K9TCC\#1Lilly & High & High & NR & Low & High & High & Moderate & High & NR & NR & [7] \\
\hline K9TCC\#2Dakota & High & High & NR & Low & High & High & Moderate & High & NR & NR & [7] \\
\hline K9TCC\#4Molly & Low & Moderate & NR & Low & Moderate & High & Moderate & High & NR & NR & [7] \\
\hline K9TCC\#5Lilly & Moderate & Moderate & NR & Low & High & Moderate & Moderate & High & NR & NR & [7] \\
\hline TihoDUrtTCC1506 & Low & High & High & Low & NR & NR & NR & High & Moderate & NR & [10] \\
\hline
\end{tabular}

In vitro studies using BC cell lines play a significant role in the novel drug discovery and development process, providing crucial data on drug effects in the early preclinical stages. Such information is of paramount importance in the decision-making process for drugs moving forward into more expensive and time-consuming in vivo clinical trials. Initial studies using canine TCC cell lines were extensively focused on non-selective cyclooxygenase inhibitors (Cox inhibitors, non-steroidal anti-inflammatory drugs-NSAIDs) and various chemotherapeutic agents [4]. Following the clinical trials with pet dogs, therapy with NSAIDs, with or without the addition of chemotherapeutics became the standard of care for canine invasive and metastatic TCC $[13,14]$. However, the overall median survival time for dogs that respond to NSAIDs and chemotherapy was still relatively short (up to a few months), which led to the search for novel therapeutic agents. In the past years, multiple studies including canine $\mathrm{BC}$ cell lines were conducted in order to evaluate the activity of novel anticancer agents (Table 3) [15-25]. Although many of them were not transferred to in vivo studies, novel therapeutic agents that could improve survival of dog pets with bladder TCC were also found. One of the most promising directions was molecular-targeted therapy using receptor tyrosine kinase inhibitors. As an example, Sakai et al. demonstrated that lapatinib (tyrosine kinase inhibitor of HER2 and EGFR) could inhibit canine BC cell growth in vitro [20]. Subsequently, Maeda et al. showed that compared to the dogs treated with piroxicam alone, those administered the lapatinib had a significantly greater reduction in the size of the primary bladder tumor and improved overall and progression-free survival [26]. 
Table 3. Examples of in vitro studies using canine bladder cancer cell lines to assess the efficacy of therapeutic agents.

\begin{tabular}{|c|c|c|c|c|}
\hline Author & Therapeutic Agent & Cell Lines Used & Main Results & Reference \\
\hline Knapp et al. & $\begin{array}{c}\text { Piroxicam } \\
\text { (COX-2 inhibitor) }\end{array}$ & К9TCC & $\begin{array}{c}\text { Piroxicam had no direct } \\
\text { cytotoxicity against canine BC } \\
\text { cells } \\
\text { Piroxicam increased cytotoxicity } \\
\text { of chemotherapeutic agents }\end{array}$ & [4] \\
\hline Galvao et al. & $\begin{array}{c}\text { Gemcitabine }+ \\
\text { carboplatin } \\
\text { (chemotherapeutic } \\
\text { drugs) }\end{array}$ & $\begin{array}{l}\text { K9TCC-PU: -AxA, } \\
\text {-AxC, -Pu, -Sh }\end{array}$ & $\begin{array}{c}\text { The combination of gemcitabine } \\
\text { and carboplatin had synergistic } \\
\text { antitumor effects on canine BC } \\
\text { cells }\end{array}$ & [15] \\
\hline Rathore et al. & $\begin{array}{l}\text { AD198 } \\
\text { (derivate of doxorubicin, } \\
\text { chemotherapeutic drug) }\end{array}$ & $\begin{array}{l}\text { K9TCC\#Lillie, } \\
\text { K9TCC\#2Dakota, } \\
\text { K9TCC\#4Molly }\end{array}$ & $\begin{array}{l}\text { AD198 inhibited cell viability of } \\
\text { canine BC cells more efficiently } \\
\text { as compared to doxorubicin at } \\
\text { the same concentration }\end{array}$ & [16] \\
\hline Gustafson et al. & $\begin{array}{c}\text { Cyclopamine } \\
\text { GANT6 } \\
\text { (hedgehog signaling } \\
\text { pathways inhibitors) } \\
\text { KPT-185 }\end{array}$ & K9TCC, K9TCC-PU-Sh & $\begin{array}{l}\text { Cyclopamine and GANT6 led to } \\
\text { significantly decreased canine } \\
\text { BC cells proliferation but had a } \\
\text { smaller effect on apoptosis }\end{array}$ & [17] \\
\hline Grayton et al. & $\begin{array}{c}\text { KPT-335 } \\
\text { (selective inhibitors of } \\
\text { nuclear export) }\end{array}$ & Bliley & $\begin{array}{c}\text { Canine BC cells were resistant to } \\
\text { both drugs }\end{array}$ & [18] \\
\hline Bourn et al. & $\begin{array}{c}\text { Axitinib } \\
\text { Masitinib } \\
\text { (receptor tyrosine kinase } \\
\text { inhibitors) }\end{array}$ & $\begin{array}{l}\text { K9TCC\#1Lillie, } \\
\text { K9TCC\#5Lilly }\end{array}$ & $\begin{array}{l}\text { Axitinib and masitinib inhibited } \\
\text { cell viability and increased } \\
\text { apoptosis in a dose-dependent } \\
\text { manner in tested canine BC cell } \\
\text { lines }\end{array}$ & [19] \\
\hline Sakai et al. & $\begin{array}{c}\text { Lapatinib } \\
\text { (tyrosine kinase inhibitor } \\
\text { of HER2 and EGFR) }\end{array}$ & LCTCC, MCTCC & $\begin{array}{c}\text { Lapatinib inhibited canine } B C \\
\text { cell growth in a dose-dependent } \\
\text { manner }\end{array}$ & [20] \\
\hline Cronise et al. & $\begin{array}{l}\text { Vemurafenib } \\
\text { (BRAF inhibitor) }\end{array}$ & Bliley & $\begin{array}{l}\text { BRAF mutant BC cell lines were } \\
\text { insensitive to vemurafenib }\end{array}$ & [21] \\
\hline Hurst et al. & $\begin{array}{l}\text { Mavacoxib } \\
\text { (selective COX-2 } \\
\text { inhibitor) }\end{array}$ & $\begin{array}{l}\text { K9TCC, K9TCC-PU: } \\
\text {-AxA, - In, -Sh }\end{array}$ & $\begin{array}{l}\text { Mavacoxib reduced cell viability } \\
\text { in a dose-dependent manner in } \\
\text { all tested canine BC cell lines }\end{array}$ & [22] \\
\hline Byer et al. & $\begin{array}{l}\text { Taurolidine } \\
\text { (inhibitor of } \\
\text { angiogenesis) }\end{array}$ & Bliley & $\begin{array}{l}\text { Taurolidine showed significant } \\
\text { effects on canine BC cell viability }\end{array}$ & [23] \\
\hline Klose et al. & $\begin{array}{c}\text { Metformin } \\
\text { (biguanide } \\
\text { antihyperglycemic agent) }\end{array}$ & TCC1506 & $\begin{array}{c}\text { Metformin inhibited the } \\
\text { metabolic activity and cell } \\
\text { proliferation of the canine BC } \\
\text { cells }\end{array}$ & [24] \\
\hline Korec et al. & $\begin{array}{c}\text { Toceranib } \\
\text { (multi-target receptor } \\
\text { tyrosine kinase inhibitor) }\end{array}$ & $\begin{array}{l}\text { K9TCC-PU-AxA, -AxC, } \\
\text {-Nk, -Pu, -Sh }\end{array}$ & $\begin{array}{c}\text { Toceranib at physiologically } \\
\text { relevant concentrations has no } \\
\text { direct anti-proliferative effect on } \\
\text { canine BC cells }\end{array}$ & [25] \\
\hline
\end{tabular}

Abbreviations: $\mathrm{BC}=$ bladder cancer; $\mathrm{COX}=$ cyclooxygenase; $\mathrm{EGFR}=$ epidermal growth factor receptor; $\mathrm{HER} 2=$ human epidermal growth factor receptor 2.

Canine $\mathrm{BC}$ cell lines can be also used for investigation of other forms of anti-cancer therapy. As an example, Parfitt et al. investigated and characterized the radiosensitivity and capacity for cellular damage repair of canine BC cell lines [27]. Authors found that canine BC cell lines were moderately radioresistant and exhibited a high repair capacity. They concluded that larger radiation doses may be optimal for the treatment of naturally occurring BC in dogs [27]. In another study conducted by Maeda et al., significant differences in radiosensitivity between particular canine TCC cell lines (K9TCC and Bliley) were demonstrated. Bliley cell line was classified as radioresistant and K9TCC as radiosensi- 
tive, which might be used in further investigations on predicting individual response to radiation therapy in dogs with $B C$ [28].

Conventional 2D cultures have several advantages supporting their important role in preclinical research. Research using cell lines is significantly less expensive than in vivo animal studies and provide an unlimited supply of material, which is widely available and easy to propagate under completely controlled and reproducible environmental conditions [29]. Nevertheless, 2D cell lines do not faithfully reflect the conditions prevailing in vivo since proper tissue structure and interactions with tumor microenvironment (TME), extracellular matrix (ECM), and host immune cells (ICs) are lost [30]. Moreover, the use of $2 \mathrm{D}$ cultures is usually restricted to one cell type, while tumors in vivo are frequently heterogenous in terms of the forming cell populations, being composed either by neoplastic cells or by stromal and ICs [29]. During each passage, cultured cells could experience genetic alterations due to selective pressure, which may lead to substantial changes in their phenotype. Unlimited access to oxygen and nutrients, unlike in vivo, can also induce accumulation of genetic changes that are not found in the primary lesions $[29,30]$.

\subsection{Three Dimensional (3D) Models}

The importance of the three-dimensional (3D) features of solid tumors in relation to carcinogenesis or drug response process has prompted efforts to develop in vitro models mimicking in vivo tumor growth more precisely. Examples of 3D culture systems include multicellular aggregates grown as spheroids, scaffold-based models grown within polymer networks, and organoids defined as stem cell-containing self-organizing structures possessing multiple features of the original tumor [31,32]. Despite the increasing number of human studies using 3D models of BC, reports on canine models are still scarce.

The first 3D models of canine BC were established by Elbadawy et al. [33]. They generated four $\mathrm{BC}$ organoids using cells from urine samples collected from dogs with urothelial BC. Collected cells were mixed with natural polymer (Matrigel) and cultured with stem cell-stimulated medium. Established organoids had a spheroidal structure and a similar histology to naturally occurring BC in dogs. They were characterized by expression of urothelial cell markers and resembled the cellular architecture of invasive type of canine BC. Initial molecular characterization of established canine BC organoids has been performed and several novel genes were found to be specifically upregulated, being potential targets for novel therapies. Expression of several basal cell markers was found to be upregulated in generated organoids, suggesting that the cell origin of $\operatorname{dog} \mathrm{BC}$ might be basal, which corresponds with poor response to chemotherapy in advanced stages. In a cell viability assay, the response to treatment with a range of anticancer drugs (e.g., cisplatin, vinblastine, gemcitabine, or piroxicam) was markedly different in each BC organoid, which forms the basis for further extensive research [33]. In addition, authors provided data on novel therapeutic agents, trametinib and verteporfin, which significantly inhibited the $B C$ organoid viability. Additionally, trametinib induced basal to luminal differentiation of BC organoids, enhancing the sensitivity of cancer cells to carboplatin [34]. In another available study, the same research team demonstrated feasibility of performing 2D culture conditions using patient-derived 3D organoid cells without losing their characteristics, such as marker expression or stemness, creating a "2.5D" organoid canine BC model [35].

$3 \mathrm{D}$ cell culture approaches hold great potential and offer complex systems for various purposes, such as disease modeling and investigation of anticancer drug efficacy. The similarities in the drug responsiveness among the 3D in vitro models and the in vivo models might largely be due to their similarities in enhanced cellular interactions via adhesion and secretion of soluble factors of tumors [31,36]. These new findings support the notion that cancer drugs which are currently being tested need to be screened using more complex tissue-like systems, rather than by using conventional 2D cultures that do not fully manifest features of in vivo tumors. However, 3D models are significantly more expensive than conventional 2D cultures, mainly due to the high cost of processing. In 
addition, current 3D models of $\mathrm{BC}$ are limited by a relatively narrow range of physical properties $[31,36]$.

\section{Conclusions}

Although significant advances have been made over the past years, modeling the complexity of canine $\mathrm{BC}$ in in vitro models has not been completely successful. There are still various challenges, including the need for extensive molecular characterization of existing cell lines or creation of new reliable 3D models, incorporating multicellular cultures and diverse cellular microenvironments. So far, results obtained by in vitro and in vivo research should be interpreted together. With the constantly growing complexity of in vitro models of $\mathrm{BC}$ cancer, animal-based research might be reduced in the future

Author Contributions: Conceptualization, A.P.; methodology, Ł.N. and A.P.; software, Ł.N. and A.P.; validation, Ł.N. and A.P.; formal analysis, Ł.N. and A.P., investigation, Ł.N., W.K., B.M., T.S. and A.P.; resources, Ł.N., W.K., B.M., T.S. and A.P.; data curation, Ł.N.; writing-original draft preparation, Ł.N., W.K., B.M., T.S. and A.P.; writing-review and editing, Ł.N. and A.P.; visualization, Ł.N. and A.P.; supervision, A.P.; project administration, A.P.; funding acquisition, not applicable. All authors have read and agreed to the published version of the manuscript.

Funding: This research received no external funding.

Data Availability Statement: Not applicable.

Conflicts of Interest: The authors declare no conflict of interest.

\section{References}

1. Knapp, D.W.; Ramos-Vara, J.A.; Moore, G.E.; Dhawan, D.; Bonney, P.L.; Young, K.E. Urinary bladder cancer in dogs, a naturally occurring model for cancer biology and drug development. ILAR J. 2014, 55, 100-118. [CrossRef] [PubMed]

2. Knapp, D.W.; Dhawan, D.; Ramos-Vara, J.A.; Ratliff, T.L.; Cresswell, G.M.; Utturkar, S.; Sommer, B.C.; Fulkerson, C.M.; Hahn, N.M. Naturally-occurring invasive urothelial carcinoma in dogs, a unique model to drive advances in managing muscle invasive bladder cancer in humans. Front. Oncol. 2019, 9, 1493. [CrossRef] [PubMed]

3. Mutsaers, A.J.; Widmer, W.R.; Knapp, D.W. Canine transitional cell carcinoma. J. Vet. Intern. Med. 2003, 17, 136-144. [CrossRef] [PubMed]

4. Knapp, D.W.; Chan, T.C.; Kuczek, T.; Reagan, W.J.; Park, B. Evaluation of in vitro cytotoxicity of nonsteroidal anti-inflammatory drugs against canine tumor cells. Am. J. Vet. Res. 1995, 56, 801-805.

5. Dhawan, D.; Ramos-Vara, J.A.; Stewart, J.C.; Zheng, R.; Knapp, D.W. Canine invasive transitional cell carcinoma cell lines: In vitro tools to complement a relevant animal model of invasive urinary bladder cancer. Urol. Oncol. Semin. Orig. Investig. 2009, 27, 284-292. [CrossRef]

6. Urbasic, A.S.; Hynes, S.; Somrak, A.; Contakos, S.; Rahman, M.M.; Liu, J.; MacNeill, A.L. Oncolysis of canine tumor cells by myxoma virus lacking the serp2 gene. Am. J. Veter- Res. 2012, 73, 1252-1261. [CrossRef]

7. Rathore, K.; Cekanova, M. Animal model of naturally occurring bladder cancer: Characterization of four new canine transitional cell carcinoma cell lines. BMC Cancer 2014, 14, 465. [CrossRef]

8. Yamazaki, H.; Iwano, T.; Otsuka, S.; Kagawa, Y.; Hoshino, Y.; Hosoya, K.; Okumura, M.; Takagi, S. SiRNA knockdown of the DEK nuclear protein mRNA enhances apoptosis and chemosensitivity of canine transitional cell carcinoma cells. Vet. J. 2015, 204, 60-65. [CrossRef]

9. Shapiro, S.G.; Knapp, D.W.; Breen, M. A cultured approach to canine urothelial carcinoma: Molecular characterization of five cell lines. Canine Genet. Epidemiol. 2015, 2, 15. [CrossRef]

10. Packeiser, E.-M.; Hewicker-Trautwein, M.; Thiemeyer, H.; Mohr, A.; Junginger, J.; Schille, J.T.; Escobar, H.M.; Nolte, I. Characterization of six canine prostate adenocarcinoma and three transitional cell carcinoma cell lines derived from primary tumor tissues as well as metastasis. PLoS ONE 2020, 15, e0230272. [CrossRef]

11. Fowles, J.S.; Dailey, D.D.; Gustafson, D.L.; Thamm, D.; Duval, D.L. The Flint Animal Cancer Center (FACC) canine tumour cell line panel: A resource for veterinary drug discovery, comparative oncology and translational medicine. Veter- Comp. Oncol. 2017, 15, 481-492. [CrossRef] [PubMed]

12. Das, S.; Idate, R.; Cronise, K.E.; Gustafson, D.L.; Duval, D.L. Identifying candidate druggable targets in canine cancer cell lines using whole-exome sequencing. Mol. Cancer Ther. 2019, 18, 1460-1471. [CrossRef] [PubMed]

13. Knapp, D.W.; Glickman, N.W.; Widmer, W.R.; DeNicola, D.B.; Adams, L.G.; Kuczek, T.; Bonney, P.L.; DeGortari, A.E.; Han, C.; Glickman, L.T. Cisplatin versus cisplatin combined with piroxicam in a canine model of human invasive urinary bladder cancer. Cancer Chemother. Pharmacol. 2000, 46, 221-226. [CrossRef] [PubMed] 
14. Mohammed, S.I.; Craig, B.A.; Mutsaers, A.J.; Glickman, N.W.; Snyder, P.W.; deGortari, A.E.; Schlittler, D.L.; Coffman, K.T.; Bonney, P.L.; Knapp, D.W. Effects of the cyclooxygenase inhibitor, piroxicam, in combination with chemotherapy on tumor response, apoptosis, and angiogenesis in a canine model of human invasive urinary bladder cancer. Mol. Cancer Ther. 2003, 2, 183-188.

15. de Brito Galvao, J.F.; Kisseberth, W.C.; Murahari, S.; Sutayatram, S.; Chew, D.J.; Inpanbutr, N. Effects of gemcitabine and gemcitabine in combination with carboplatin on five canine transitional cell carcinoma cell lines. Am. J. Vet. Res. 2012, 73, 1262-1272. [CrossRef]

16. Cekanova, M.; Rathore, K. A novel derivative of doxorubicin, AD198, inhibits canine transitional cell carcinoma and osteosarcoma cells in vitro. Drug Des. Dev. Ther. 2015, 9, 5323-5335. [CrossRef]

17. Gustafson, T.L.; Kitchell, B.E.; Biller, B. Hedgehog signaling is activated in canine transitional cell carcinoma and contributes to cell proliferation and survival. Vet. Comp. Oncol. 2017, 15, 174-183. [CrossRef]

18. Grayton, J.E.; Miller, T.; Wilson-Robles, H. In vitroevaluation of Selective Inhibitors of Nuclear Export (SINE) drugs KPT-185 and KPT-335 against canine mammary carcinoma and transitional cell carcinoma tumor initiating cells. Vet. Comp. Oncol. 2017, 15, 1455-1467. [CrossRef]

19. Bourn, J.; Cekanova, M. Cyclooxygenase inhibitors potentiate receptor tyrosine kinase therapies in bladder cancer cells in vitro. Drug Des. Dev. Ther. 2018, 12, 1727-1742. [CrossRef]

20. Sakai, K.; Maeda, S.; Saeki, K.; Nakagawa, T.; Murakami, M.; Endo, Y.; Yonezawa, T.; Kadosawa, T.; Mori, T.; Nishimura, R.; et al. Anti-tumour effect of lapatinib in canine transitional cell carcinoma cell lines. Vet. Comp. Oncol. 2018, 16, 642-649. [CrossRef]

21. Cronise, K.E.; Hernandez, B.G.; Gustafson, D.L.; Duval, D.L. Identifying the ErbB/MAPK signaling cascade as a therapeutic target in canine bladder cancer. Mol. Pharmacol. 2019, 96, 36-46. [CrossRef] [PubMed]

22. Hurst, E.A.; Pang, L.Y.; Argyle, D.J. The selective cyclooxygenase-2 inhibitor mavacoxib (Trocoxil) exerts anti-tumour effects in vitro independent of cyclooxygenase-2 expression levels. Vet. Comp. Oncol. 2019, 17, 194-207. [CrossRef] [PubMed]

23. Byer, B.; Schlein, L.J.; Rose, B.; Séguin, B. In-vitro effects of taurolidine alone and in combination with mitoxantrone and/or piroxicam on canine transitional cell carcinoma. Can. J. Vet. Res. 2020, 84, 115-123. [PubMed]

24. Klose, K.; Packeiser, E.-M.; Müller, P.; Granados-Soler, J.L.; Schille, J.T.; Goericke-Pesch, S.; Kietzmann, M.; Escobar, H.M.; Nolte, I Metformin and sodium dichloroacetate effects on proliferation, apoptosis, and metabolic activity tested alone and in combination in a canine prostate and a bladder cancer cell line. PLOS ONE 2021, 16, e0257403. [CrossRef]

25. Korec, D.I.; Louke, D.S.; Breitbach, J.T.; Geisler, J.A.; Husbands, B.D.; Fenger, J.M. Characterization of receptor tyrosine kinase activation and biological activity of toceranib phosphate in canine urothelial carcinoma cell lines. BMC Vet. Res. 2021, 17, 320. [CrossRef]

26. Maeda, S.; Sakai, K.; Kaji, K.; Iio, A.; Nakazawa, M.; Motegi, T.; Yonezawa, T.; Momoi, Y. Lapatinib as first-line treatment for muscle-invasive urothelial carcinoma in dogs. Sci. Rep. 2022, 12, 4. [CrossRef]

27. Parfitt, S.L.; Milner, R.J.; Salute, M.E.; Hintenlang, D.E.; Farese, J.P.; Bacon, N.J.; Bova, F.J.; Rajon, D.A.; Lurie, D.M. Radiosensitivity and capacity for radiation-induced sublethal damage repair of canine transitional cell carcinoma (TCC) cell lines. Vet. Comp. Oncol. 2011, 9, 232-240. [CrossRef]

28. Maeda, J.; Froning, C.E.; Brents, C.A.; Rose, B.J.; Thamm, D.H.; Kato, T.A. Intrinsic radiosensitivity and cellular characterization of 27 canine cancer cell lines. PLoS ONE 2016, 11, e0156689. [CrossRef]

29. Wilding, J.L.; Bodmer, W. Cancer cell lines for drug discovery and development. Cancer Res. 2014, 74, 2377-2384. [CrossRef]

30. Riedl, A.; Schlederer, M.; Pudelko, K.; Stadler, M.; Walter, S.; Unterleuthner, D.; Unger, C.; Kramer, N.; Hengstschläger, M.; Kenner, L.; et al. Comparison of cancer cells in $2 \mathrm{D}$ vs $3 \mathrm{D}$ culture reveals differences in AKT-mTOR-S6K signaling and drug responses. $J$. Cell Sci. 2017, 130, 203-218. [CrossRef]

31. Vasyutin, I.; Zerihun, L.; Ivan, C.; Atala, A. Bladder organoids and spheroids: Potential tools for normal and diseased tissue modelling. Anticancer Res. 2019, 39, 1105-1118. [CrossRef] [PubMed]

32. Roy, V.; Magne, B.; Vaillancourt-Audet, M.; Blais, M.; Chabaud, S.; Grammond, E.; Piquet, L.; Fradette, J.; Laverdière, I.; Moulin, V.J.; et al. Human organ-specific 3D cancer models produced by the stromal self-assembly method of tissue engineering for the study of solid tumors. BioMed Res. Int. 2020, 2020, 6051210. [CrossRef] [PubMed]

33. Elbadawy, M.; Usui, T.; Mori, T.; Tsunedomi, R.; Hazama, S.; Nabeta, R.; Uchide, T.; Fukushima, R.; Yoshida, T.; Shibutani, M.; et al. Establishment of a novel experimental model for muscle-invasive bladder cancer using a dog bladder cancer organoid culture. Cancer Sci. 2019, 110, 2806-2821. [CrossRef] [PubMed]

34. Elbadawy, M.; Sato, Y.; Mori, T.; Goto, Y.; Hayashi, K.; Yamanaka, M.; Azakami, D.; Uchide, T.; Fukushima, R.; Yoshida, T.; et al. Anti-tumor effect of trametinib in bladder cancer organoid and the underlying mechanism. Cancer Biol. Ther. 2021, 22, 357-371. [CrossRef]

35. Abugomaa, A.; Elbadawy, M.; Yamanaka, M.; Goto, Y.; Hayashi, K.; Mori, T.; Uchide, T.; Azakami, D.; Fukushima, R.; Yoshida, T.; et al. Establishment of 2.5D organoid culture model using 3D bladder cancer organoid culture. Sci. Rep. 2020, 10, 9393. [CrossRef]

36. Wang, S.; Gao, D.; Chen, Y. The potential of organoids in urological cancer research. Nat. Rev. Urol. 2017, 14, 401-414. [CrossRef] 